\title{
PEDAGOGY UNDER SIEGE IN PALESTINE: INSIGHTS FROM PAULO FREIRE ${ }^{1}$
}

\section{Published by Holy Land Studies, Vol, 13 no. 1 pp. 71-87}

\author{
Ms Najwa Silwadi \\ Lecturer, Social Work Department and \\ Director of the Center for Communication Action \\ Al-Quds University \\ Jerusalem, Palestine \\ najwa.silwadi@gmail.com \\ and

\section{Professor Peter Mayo} \\ Department of Education Studies \\ Faculty of Education \\ University of Malta, \\ Msida MSD 2080, \\ Malta \\ peter.mayo@um.edu.mt
}

\section{ABSTRACT}

This paper analyses the relevance of Paulo Freire's pedagogical and philosophical ideas within the context of occupied Palestine. It specifically focuses on the work in continuing community action and education carried out by a particular centre established at Al-Quds University in Jerusalem, and at the heart of the 'old city', for this purpose. The major focus here is on community theatre foregrounding issues related to women in Palestinian society. Major themes broached include" the politics of education, social mobilization, women and the Intifada, the collective dimensions of knowledge,

1 The following essay is part of the Tempus project "Lifelong Learning in Palestine" ( LLIPS) This collaborative project seeks to develop Lifelong Learning in formal and non-formal networks in Palestine beginning in 2011 and scheduled to end in 2013(Hammond, 2012). It links the work of universities to centers outside of the university in civil society. As part of the project, seminars and workshops will develop pedagogic partnerships in different settings, facilitating a wide arrangement of adult learning right across Palestinian society. Palestinian institutions of Lifelong Learning will also link innovative work in Lifelong Learning to different regions in Europe and the Arab world. 
learning and praxis, purging oneself of the 'oppressor within' to break the cycle of violence, education for liberation.

\section{Introduction: The Politics of Education}

That education IS politics is a 'given' for those who pursue a critical approach to education. There is a long tradition of educational activity driven by this view of education, a tradition which includes exponents of 'independent working class education' (Waugh, 2009), popular education in Latin America (Kane, 2001; Torres, 2013) and education among political prisoners in a variety of contexts and which heralds the efforts of a number of key figures in revolutionary politics such as Rosa Luxemburg, Antonio Gramsci, Fidel Castro, Nelson Mandela, Frei Betto and of course prisoners of conscience in Ansar III in the Al-Naqab Desert ("Negev Desert") of Palestine (Sacco, 2002).

If there is one country in the world where people need no reminding that education is politics then that is definitely Palestine. In contexts under siege, the political importance of education is driven home forcibly either through denial of access to it or through forms of resistance and cultural resilience that involve a strong international dimension.

Education in Palestine is unique because it is one of the very few places in the world that has been forced to develop under continuous challenges from external forces. Historically Palestinian education was controlled by the Ottoman Government. Under the post-World War I British Mandate, Britain set up separate education systems for the Jewish and Palestinian populations, granting autonomy to the Jewish schools but not to Palestinian schools where they sought to control content in order to suppress Palestinian national aspirations (Champagne and Abu-Saad, 2006).

\section{The Palestine Nakba and its aftermath}

1948, the year the Israeli State was established, was also the year of the Palestinian Nakba or catastrophe (Masalha 2012; Masalha in Gargour, 2007) when 750,000 Palestinians were forcibly expelled from their homeland and more than 500 Palestinian villages, towns and cities were deliberately destroyed, along with their education system. Living under occupation, the Palestinian people have recognized that education is an important tool.

First, according to an estimate by BADIL, a Palestinian non-governmental organization, there were more than 7.2 million Palestinian refugees and displaced persons at the end of 2000 (IMEU, n.d.) Education became essential to ensure a secure future through employment, especially for those who lost their lands and became refugees.

Second, the Palestinians used education as a critical tool for liberation and freedom from the Israeli colonial military occupation.

Third, because one of the main objectives of the occupation to control the land and its indigenous people through a deliberate project of de-development of its capacity and elimination of Palestinian culture and identity, education was and remains a critical way to resist the occupation, maintain identity, and build an independent nation. It provides tools and means for 
survival and resistance against military occupation, dispossession and exile (Barghouti and Murray, 2005).

As argued by Hanna Nasir, tfounder and first president of Birzeit University, who was arrested by the Israeli authorities and deported to Lebanon where he was to remain in exile for the next nineteen years:

It has been my personal belief for many years that the key to the liberation of Palestine can be found in higher education.... For a society under occupation which is involved in the transition to an independent nation, higher education, such as that represented by Birzeit University, is essential as a forum for critical thinking, technical expertise, and community leadership. The close relationship between academic freedom, human rights, and the right to self-determination remains the crucible in which Palestinian higher education must develop and thrive ( in Barghouti and Murray, 2005: 3).

\section{Freire's Relevance}

Although Freire is not the only person who emphasized the notion of education as a means of liberation from oppression (Freire, 1970, 1993), his work continues to inspire multitudes of oppressed people worldwide especially Palestinians. In the Palestinian case, Freire remains a source of inspiration with his pedagogical insights and approaches which seem to lend themselves to situations of education under siege not only in a metaphorical sense but in the literal sense encountered by such beleaguered communities as are the Palestinian ones.

Education, he states, can either 'domesticate' or 'liberate' (Freire 1972). For the Palestinian people, education is conceived as a pathway to resistance and survival. The Israeli military's non-stop attacks against and closures of Palestinian schools and academic institutions as well as its positioning of military checkpoints failed to impede Palestinian access to education. Instead, Palestinians engaged in a host of creative educational means to overcome the tough and harsh measures imposed by the Israeli military. They sought to continue teaching and learning under innumerable difficult conditions, thus emulating other besieged communities such as the Poles under different occupations with their innovative approaches such as the 'flying university' (Uniwersytet Latajacy) (Buczynska-Garewicz 1985; Bron, 1995, p. 22). In the process, Palestinians obtained unique educational experience and skills. This experience was critical in shaping the ways in which people can access their rights to education, and, we argue, it constitutes a good example of how access to education can be a liberating and empowering tool for oppressed and disadvantaged groups.

\section{Education for Liberation}

A liberating education is one that fosters the disposition among learners to engage in a dialectical relationship with knowledge and society (Allman, 1999). A unidirectional, 'top-to-bottom' process of teacher-student transmission, that is often symptomatic of a wider prescriptive process of communication, constitutes a domesticating education ('banking education') (Mayo, 2004; 2009). What is called for is an authentically dialogical approach to knowledge. This entails conceiving of the 
two types of education as ends of a continuum. One struggles to reach one end of the continuum while being buffeted by various forces towards the other end. Engaging in the struggle involved is tantamount to living critically. While some form of transmission is perforce required, too much transmission, in a one-way traffic approach, can well serve to replicate the form of prescription that characterizes diktats in a situation such as that in Palestine, where an external force is in control and issues communiqués in a classic case of what Edward Said calls 'direct colonialism', that is, a situation characterized by the presence of an occupying force (Said, 1993). A complex notion of dialogue is called for. Although not on an equal footing, teachers and students learn from each other as they dialectically co-investigate the object of knowledge. (Shor and Freire, 1987; Freire, 1998) The concept that lies at the heart of this process is praxis, a very important residue of the Hellenistic culture which persisted in the region until the Ottoman conquest, and which Arabs, through their work of translation in Cordoba and other centers of learning, helped preserve for posterity (see Lê Thánh Khôi, 2000; Wallace-Murphy, 2006).

\section{Praxis}

This teaching approach entails a process whereby learners and educators obtain a critical distance from the world they know to perceive it in a different and critical light. They are encouraged to "extraordinarily re-experience the ordinary," as critical educator Ira Shor $(1980,1987)$ once put it. The community in which the learning setting is situated is researched beforehand by a team of educators and project participants (including learners). The research includes informal meetings with members of the community, close observation of their speech patterns, obtaining knowledge of the community members' concerns etc. The insights, information and knowledge derived from this research are codified into learning material. It can take the form of a play, a photograph, a painting, a mural etc. This material is intended to enable learners from the same community to obtain critical distance from it to be able to unveil collectively and with the help of the educator, who also learns from these insights and dialogical interactions with the group, the underlying contradictions of the society in question. Critical distance is that which can help persons avoid educational cul-de-sacs. It keeps them from reproducing in many ways the form of oppression against which they are struggling.

Emphasis is placed on dialogue and on the 'pedagogy of the question' (Bruss and Macedo 1985). Knowledge is problematised. The spaces carved up for the education of an oppressed people should, if possible, be spaces where one can engage in the kind of dialogue and problem-posing interaction denied by institutionalized education. Institutionalized education is often characterized by curricular impositions (although some critical educators manage, against all odds, to carve out spaces also within the interstices of the system itself, serving as disrupting mediators in the process of cultural transmission). It is also denied by the more general social situation characterized by a top down, repressive communicative approach favored by the oppressors. Things are called into question in what is a "problem-posing" rather than a "problem solving" approach. There does not have to be a straight answer to any problem posed. It can well be a case of posing further questions regarding complex situations than simply providing answers. The object of knowledge is an object of co-investigation (Freire, 1998a). Knowledge is therefore not something possessed by the educator which he or she 
transfers to the learner but is something both educator and learner co-investigate and explore together. Knowledge is therefore conceived of as dynamic rather than static.

\section{Palestinian Women}

Palestinian society learned from the legacies of the Cordoba experience and much more recent learning experiences. Palestinians realized that the role of educational institutions must be more than simply conveying information and teaching skills to privileged students inside the universities' campuses. As Nahla Abdo (in Borg and Mayo, 2007, p. 24) states: "it goes without saying that due to the historical, political and quite specific circumstances of Palestinians, the Palestinian women's movement stood up as a particularly strong movement, leading in some areas. This is partly demonstrated by the establishment of the first ever Ministry of Women's Affairs in the Middle East." This also indicative of a growing women's movement in the Arab world, a point registered by both Nahla Abdo and Edward Said, the latter in conversations with David Barsmian (ibid, pp. 24, 25)

Palestinian women have been playing a key role in community organization and mobilization since the first Intifada, the uprising in 1987 (Lockman and Beinin, 1989; King, 2007). In the beginning, women were given training and means to support their own households and participate in the uprising. New organizations were formed in each neighborhood to address the different problems resulting from the occupation. Women were the majority of the participants ${ }^{2}$. They had to fill in the gaps in services resulting from the struggle to keep their neighborhoods and families together. Women grew "victory gardens" for personal and market use, they raised animals, and grew crops, pickles, preserved fruit and vegetables, made jams and ice cream, and stockpiled food for when curfews were implemented. Women circulated the United National Leadership's bayanat (leaflets), which informed the rest of the community of the strike dates, and outlined behavior rules. ${ }^{3}$ Grassroots activities gave women the space to learn and to teach each other and their community, and not only to taste independence, but also to create more jobs. Women played key roles in education committees and taught the pupils when the schools shut during the strict curfews. When the neighborhood committees were outlawed in August 1988, women still taught classes in their homes at great personal risk, a common international feature of education under siege. Teaching was used as a tool for self-realization and to promote active resistance.

\section{Women and Al-Quds University}

Palestinian women feature prominently in the continuing education work of one particular Palestinian university situated in Jerusalem/Al-Quds. Al-Quds University creates a bottom-up learning process between the university and the community. The Community Action Center (henceforth CAC emerged from this community-based practice when it was established, as part of Al-Quds University, in 1998 as a non-profit community rights-based organization. CAC is one of the ways by which the university contributes to the development of the Palestinian community. CAC is located at the heart of the

\footnotetext{
${ }^{2}$ http://sarah-levene.blogspot.com/2011/10/what-was-role-of-palestinian-women

${ }^{3}$ http://sarah-levene.blogspot.com/2011/10/what-was-role-of-palestinian-women
} 
community of the 'Old City' of East Jerusalem. Its work is led by a team of professional staff made up of Palestinian lawyers, social workers and training, administrative and communications officers, with thousands of volunteers and community members as participants.

It The Centre and its educators explore the centrality of this 'bottom up' approach to individual, group and community empowerment of Palestinians who are denied basic social, economic and legal rights. The community rights-based participation (CRBP) process is sharing and fostering awareness of individuals, groups and community and facilitating their access to civil entitlements and legal rights. This process helps them to navigate the complex and discriminatory Israeli government bureaucracy in order to protect Palestinian citizens from eviction or to ensure their access to and benefit from basic health services, education, and other social services and to achieve social change.

According to Fletcher (2003), we can trace the origins of community-based practice research as grassroots action to a current of thought and praxis in education, development, social science and health work that recognized the necessity of incorporating local realities into all aspects of program design.

Individuals come to CAC to share their personal story; they discuss their experience of denials of basic rights and they identify their struggles for their rights to health and education. This process is based on teamwork where individuals learn how to access their rights and interests and how to protect their rights and to live with dignity. At the community level public meetings are organized with community members from different backgrounds to learn about their story of now and to learn about the story of us, as a team we learn about the challenges that face the community members' interests, values, and why they are at stake (Ganz, 2007). The focus is on obtaining knowledge, and insights and engaging community members to realize change at the individual, community, and social levels. This process takes different forms, such as:

- Providing relevant information quickly, offering support, advocating on behalf of individuals and empowering Jerusalemites with the tools necessary for them to advocate on their own behalf.

- Working to respond to the specific needs of Jerusalemite women and to enable these women to realize their social and economic potential within their community, and to strengthen their current role in society by providing them with suitable opportunities through communal education and by building on the rich experiences and contributions to society of Palestinian women.

- Organizing community education activities to support the right to education of the community members that have been denied access to study. This includes different programs, like the Debate Forum for university students, for example, where the aim is to enrich the democratic environment in the university, to rehabilitate the mind to address differences and contradictions within society without resorting to repression or violence, and to sharpen students' ability to argue by enhancing their skills in reading, analyzing and critical thinking.

This approach comes into fruition in a variety of ways not least through the use of community theatre which has a long tradition including the Spanish poet Federico Garcia Lorca and his troupe of players, La Barracca (the shack), as well as the major recipient and source of creative reinvention of Freire's ideas, the recently deceased Augusto Boal (English and Mayo, 2012). Community theatre has also 
made its presence felt in the Middle East as indicated by articles documenting the work of such groups as the El Warsha Theatre Company in Egypt engaging in street theatre in villages in different parts of the region. Hasan El-Geretly (2002), El Warsha's founder and director, states:

the troupe directed its attention to the construction and architecture of the theatrical work itself to incorporate our own particular vision of the world, without which both material and spirit are lost (p. 72)

There is therefore a Middle Eastern point of reference on which to draw. In addition there is also the work of Freire and Boal (1995) which resonates with the kind of oppressive experiences that obtain in this part of the world. Their pedagogical approaches and type of community action have worldwide resonance through grassroots theatre companies such as Third-Way Theatre (Australia), Drama for Life (South Africa), The Justice Theater Project (USA), Puppet Underground (USA), Acting for Change (UK), Teatro Giolly (Italy) and The Freedom Theatre (OPT). This theatrical approach to critical pedagogy has not been lost on besieged and dispossessed ${ }^{4}$ peoples such as the Palestinians, and specifically Palestinian women, as the following project reveals, embracing as it does many of the concepts linked with Freire and critical pedagogy.

\section{Radical Gender-Based Theatre (RGBT) and Community Engagement}

The Radical Gender-Based Theatre (henceforth RGBT) is an example of the university-community engagement in education placing emphasis on dialogue and on the potentially dynamic "pedagogy of the question.' CAC launched the RGBT in September 2011 with eleven weekly four-hour workshops attended by eight female students from Al-Quds University coached by a volunteer grounded in gender studies and theatre. The aim of the RGBT, composed solely of women, is to stimulate and implement social awareness, development, emancipation and change within the Palestinian community through the medium of drama. The RGBT targets women and the predicament of women exposed to the oppression of a military occupation as well as to the constraints experienced as a result of living in an often restrictive community, with heavy family and religious traditions.

The actors and audience were to become leaders for change by learning the language of dialogue and using the tools of theatre to break down barriers.

- The idea of RGBT is the brainchild of a young Palestinian from inside the Green line (1948 Occupied Palestine). Shab Abed, adept and skilled in theatre training and gender issues, uses music and singing as educational tools to generate social awareness, development and change through messages aimed to engender a change in different community issues, including the issues of feminism.

- The eight female participants in the first year of the project had all suffered persecution and came from different backgrounds: some from poor families, others from rich families, some were married and mothers as well as students at the university, some from very conservative families, committed to wear the hijab, while others do not follow such traditions. Participants are studying to be physicians, social workers, teachers, or journalists. Some have lived all their lives in a refugee camp, others in the city, and still others live in a small town. But they are all female, Palestinian, living under occupation and students at Al-Quds University.

\footnotetext{
${ }^{4}$ There are strong links with other dispossessed people such as the sem terra (MST-landless people) in Brazil.
} 
- The team was assembled as a result of collaboration involving students, teachers, artists, and community organizers. The curriculum is designed to

- examine both global and local systems of oppression in order to identify the common struggles which Palestinian women share with regard to gender discrimination, military occupation, and displacement,

- empower students to discover their own voices of resistance,

- break down the oppression cycles that entrap women and

- break down the stereotypes that separate us.

The pedagogy adopted stresses the following principles Interactive women-centered education. - Placing education and culture at the center of generating social change;

- Drawing on the female participants' experiences and connecting to Palestine in ways that are relevant to women's cultural situation and life under the Israeli military occupation;

- Providing the space where one can engage in the kind of dialogue and problem posing interaction denied by institutionalized education and

- Increasing the participants' awareness of how our struggles are connected to others. This can prove a powerful means of challenging the systems of oppression that negatively affect all of us.

\section{The Process Involved}

The female participants openly discussed, analyzed and researched feminist issues, freedom of expression, workers' struggles, and human rights. They expressed their views on the economic and social difficulties faced by Palestinians in general and specifically women living under the Occupation. The collective research was intended to help participants overcome a sense of alienation and generate group bonding, trust, self-assurance, assertiveness and a community spirit. The educator helped prepare the students in movement, sound, voice, expression and imagination using different theatre techniques including improvisation, which eventually enabled the translation and depiction of personal experiences of oppression as located within a governing systemic reality.

The work is grounded in the participants' experience. Recalling her process of learning within the GBRT, Ahlam, one of the participants, said: "I always said to Shab Abed, when he asked me about something that happened, 'It is normal, ordinary'. And, I used to add, 'I don't know why you think it isn't'." It was not only Ahlam but Safia, Quds and all the group members who usually started their learning process with this perception that was different from that of their teacher Shab Abed.

The methodology involves praxis where the teacher and student learn from each other as they coinvestigate dialectically the object of knowledge. Shab Abed and our RGBT members obtain a critical distance from the world they know to perceive it in different and critical light. It is an amazing process to re-experience the "ordinary" world they know in a different and critical light.

The RGBT, as grassroots education, draws on a process that inspires the participants to continually reimagine what is possible both in and out of the classroom. The process is oriented to support and strengthen the capacity of individuals and communities through guidance, empowerment and support for equality and humanity. 
This collective's shared wisdom and experience was channelled in the direction of creating sketches, scenes, short plays and eventually a staged performance in front of a live audience. The first year's production comprised sketches written and acted by each student on topics such as 'sexual abuse' and 'female subservience within the family.' The production was hailed by the audience as a huge success with the female performers receiving a standing ovation. Family and friends amongst the spectators shed tears, expressed enthusiasm for the project and called for a continuation of the experience as a grassroots tool for social change in relation to women and oppression.

This work, in which CAC is engaged, is based on the belief that increasing the participants' awareness of how our struggles are connected to others can prove a powerful means of challenging the systems of oppression that negatively affect all of us. It is a way to create "a world in which it will be easier to love", to use these words from Paulo Freire in the introduction to Pedagogy of the Oppressed.

\section{Power Relations}

The roles of educator and learner are almost interchangeable, as all learn from each other, but this is not to say that the learner and educator are on an equal footing. The latter (in a situation when a formally well-prepared and educated teacher or adult educator is involved) must have a certain amount of authority (bestowed on the educator by the learner because of the former's competence in the field of learning and as a pedagogue) which should not be allowed to degenerate into authoritarianism lest the spirit of genuine dialogue would be destroyed (Freire 1974).

There are situations when learners formally act as both teachers and learners, such as within prison education where the inmates prepare subjects that they teach to others and then learn other subjects prepared by and taught to them by their mates. Hence, lifelong learning in communities and especially in communities under siege throw up situations where people have to act as both teachers and learners even in a formal ascribed sense. Castro and his imprisoned colleagues did this after being sentenced to imprisonment on the Isles of Pines ${ }^{5}$ because of the Moncada Barracks attack in 1953 (Galloway, 2006, pp. 98, 99). Earlier, Antonio Gramsci, Amadeo Bordiga and political prisoners of the Fascist regime in Italy taught themselves and others in a similar manner when interned on the island of Ustica, which served as an open prison as they awaited their trial (Gramsci, 1996, p. 27). And, according to Joe Sacco's graphic journalistic book, Palestine, Palestinian prisoners of conscience have done this in Ansar III (Sacco, 2002). Only through dialogue does the group learn collectively to unveil the contradictions that underlie the reality being focused upon. For collective learning is a feature of a genuinely empowering education, as Freire and others have underlined.

\section{Collective Dimensions of Learning}

Furthermore, the kind of pedagogy called for is also collective based on the benefits of people exploring, learning and doing things together, which goes against the grain of conventional education that promotes learning as an individual act. It goes against the grain of educating to promote the idea of atomized individuals and disconnected citizens controlled from a distance (Foucault calls this governmentality). Critical pedagogy, as promoted by Paulo Freire, John Dewey, Lorenzo Milani,

\footnotetext{
${ }^{5}$ We are indebted, for this detail, to regular Middle East Monitor correspondent, Ramona Wadi.
} 
Nahla Abdo, Eduard Lindeman, Bell Hooks, Linda Tuhiwai Smith, Paula Allman, Antonia Darder, Danilo Dolci, Luisa Muraro, Jane Thompson and other adherents to the feminist and indigenous movements, emphasise the collective dimension of learning, conceived of primarily as a social act (Taking Liberties Collective 1987).

The collective dimension is best exemplified in cases of pedagogy under siege where people denied access to formal institutions work out their own way of learning collectively not having the luxury of professional teachers but having to improvise, as they do in prisons where they reinvent themselves as educators as well as learners. They read, write and learn collectively, as did the students of Lorenzo Milani at Barbiana in a situation where school, drop outs were being taught at an improvised school lacking a complement of professionally trained teachers (Borg, Cardona and Caruana, 2009)

\section{The Intifada and Collective Learning}

Critical pedagogy, as promoted by the First Intifada, was characterized by the community working collectively. People without access to formal institutions worked out their own way of learning, using what they had to attain what they desired from educational process. This helped them to 'reinvent' themselves as educators as well as learners. As Um Zohear, 65, a volunteer at CAC, who now teaches literacy to other women who never had the chance to go to school, said, "the First Intifada changed us as women, I learned to trust myself, to challenge the difficulties and to be active to change my own family and society."6

Adult educators are encouraged to show tact when promoting dialogical relations and there are moments when they alternate dialogue with a certain degree of instruction, especially when considering that people exposed for years to banking education do not necessarily embrace dialogue easily. The starting point of co-investigation is the learner's existential reality (the situation in which one finds oneself) which is however not the be all and end all of the learning process, lest one would be guilty of populism or basismo (making people aware of their situation but keeping them there); in other words one does not remain there but gradually learns to transcend that situation. (Freire, 1994) Hence in a Boal-inspired community theatre approach, as discussed above, the starting point is a representation of aspects of the community reality which are presented in a manner that allows the spectators and actors at the same time (spectators) to gain critical distance from that which they know -the quotidian (Little, 2012). Participants, including the formal educators themselves, must have enough humility to relearn, through their dialogic interactions with the learners, that which they think they already know. This is where one moves from the stage of mundane, everyday, knowledge to that of critical awareness.

Humility itself and the realization that real human interaction has a learning dimension is born out of love, love of the world and universe, in their cosmic totality, and the human beings and other species that inhabit them. As Che Guevara would say, revolution (in the Palestinian case, this entails changing the cycle of oppression in the context of dispossessed people in and outside their own land) is an act of love. Freire, for one, conceived of the educators and learners as "integral human beings" (Darder, 2002, p. 94) in an educational process based on love (Freire, 1970a, 1993, pp. 89-90). Love characterizes the humanizing relationship between teacher and taught (teacher-student and student-

\footnotetext{
6 "Um Zohear, 65,Palestinian Women, Learning Experience from Mother to Mother.
} 
teacher, in Freire's terms). It also drives the educator forward in teaching and working for the dismantling of dehumanizing structures. One ought to recall that the entire pedagogical process practiced and articulated by Freire is based on his trust in human beings and in their ability to create "a world in which it will be easier to love" (Freire, 1970a, 1993, p.40). Freire's concept of love has strong religious overtones and revolutionary ones. This is perhaps asking a lot of a people who have been subjected, since 1947, to all sorts of violence. And yet the critical task we feel should be reflected in any educational endeavour in Palestine should be geared towards not only self-defence but also to eventually breaking the cycle of violence and retribution (Mayo, 2012), thus enabling the persons concerned to claim even further the moral high-ground, ushering in a sense of educated hope for a country or state based on peace and social justice. To do this they must reject the 'oppressor consciousness,' the 'oppressor within':

Their ideal is to be men; but for them to be men is to be oppressors. This is their model of humanity (Freire 1970a, 1993: 45).

In short, the attempt should be, as with Marx, to end the contradiction of opposites between oppressor and oppressed (Allman, 1999). Freire sees dehumanization as the key feature of the relationship between oppressor and oppressed, a dialectical relationship characterized by a unity of opposites. This relationship is characterized by 'negation', the negation of humanization.

Dehumanization which marks not only those whose humanity has been stolen, but also (though in a different way) those who have stolen it, is a distortion of the vocation of becoming more fully human. (Freire 1970a, 1993: 44)

Hence in liberating oneself one would, as Freire underlines, be liberating the oppressor. By humanizing oneself one would be, also according to Freire, humanizing the oppressors who dehumanize themselves when dehumanizing others. The two exist in a dialectical relationship. There would be no oppressor if there is no oppressed and vice versa. The target for a truly liberating Palestinian education is not to replace one oppressor with another (simply taking their place) but to abolish the oppressor-oppressed relationship altogether. This is what Freire calls 'reinventing power' as opposed to reproducing the same form of power (Freire in Gadotti, Freire and Guimarães, 1995, p.44). And one of the spaces to prefigure this situation is the learning setting where the pedagogy involved, once again based on love, should be intended to enable learners to share the power that, in traditional situations, is deposited solely in the teacher.

This pedagogical approach implies not laissez faire pedagogy (this will throw up new forms of power dynamics that are oppressive since, for instance, some persons belonging to an in-group, can abuse the situation; it can also lead to shared ignorance) but a directive pedagogy. There is a direction involved, a direction towards mental individual and collective emancipation from the manacles that after years and years of occupation and subjugation become mind-forged.

\section{Conclusion}

A series of workshops carried out, in the course of the LLIP project, at various sites within Palestine, have indicated the relevance of Paulo Freire's pedagogical approach to a people engaged in struggle to affirm their dignity and identity in a situation characterized by the presence of an occupying force. Freire's concepts of rejecting the internalization of the oppressor, of praxis, of democratic exchange, of authority and authoritarianism and of a 'pedagogy of hope,' predicated on the belief that change, 
though difficult, is possible, serve the purpose for a besieged community to retain its sense of purpose. This includes enabling the communities to come to terms with their internal contradictions. If not acknowledged and confronted, these contradictions can serve to weaken the communities in the face of relentless and systemic adversity. In this regard, the one major insight from Freire that seems to have had major resonance in the workshops is that of not harbouring the 'oppressor within', of not wanting to be like the oppressor, a ploy which would otherwise serve to exacerbate the contradictions and weaken the communities themselves. Much of the work concerned with gender relations under siege and occupation, as provided by the RGBT, hinges on this aspect of Freirean pedagogy. It is focused on breaking the cycle of violence itself which, among other things, can spill over to various parts of the besieged community itself as an unsavoury feature of gender ${ }^{7}$ and other social relations (for example, rural-urban relations).

\section{References}

Allman, P. (1999). Revolutionary social transformation: Democratic hopes, political possibilities and critical education. Westport, CT and London: Bergin \& Garvey.

Barghouti, R, and Murra, H (2005). 'The Struggle for Academic Freedom in Palestine.' Talk delivered at Academic Freedom Conference "Problems and Challenges in Arab and African Countries", Alexandria, Egypt. Birzeit: Birzeit University's Right to Education Campaign. http://right2edu.birzeit.edu/downloads/pdfs/AcademicFreedomPaper.pdf Accessed $29^{\text {th }}$ July 2013.

Boal, A (1995) The Rainbow of Desire. The Boal Method of Theatre and Therapy, New York and London: Routledge.

Borg, C and Mayo, P (2007) Public Intellectuals, Radical Democracy and Social Movements. A Book of Interviews, New York: Peter Lang.

Borg, C., Cardona, M., \& Caruana, S. (2009). Letter to a teacher. Lorenzo Milani's contribution to critical citizenship. Malta: Agenda.

Buczynska-Garewicz, H (1985), 'The Flying University in Poland, 1978-1980', Harvard Education Review, Vol. 55, No.1 (Spring), 20-34.

Bron, A (1995) 'Adult Education and Civil Society in a Comparative and Historical Perspective' in Bron, M. Jr and Malewski, M (Eds.), Adult Education and Democratic Citizenship, Wroclaw: Wroclaw University Press.

Bruss, N., and Macedo, D. (1985). Toward a pedagogy of the question: Conversations with Paulo Freire. Journal of Education (Boston), 167, pp. 7-21.

Champagne, D, and Abu-Saad, I (2006). "Introduction: A Historical Context of Palestinian Arab Education." American Behavioral Scientist 49: 1035-050. Web accessed. 2 Apr. 2012.

Darder, A (2002). Reinventing Paulo Freire. A Pedagogy of Love. Boulder: Westview.,

\footnotetext{
${ }^{7}$ Domestic violence features

prominently in the work of several centres of continuing education and rights advocacy in the Middle East. Birzeit University's Centre for Continuing Education in Ramallah includes a centre for victims of domestic violence. The Nadim Centre in Egypt, directed by Magda Adly (see Adly in Borg and Mayo, 2007), is another prominent centre catering for victims of violence and torture including domestic violence.
} 
El-Geretly, H. (2002). From reaching in to reaching out: El-Warsha 1987-1999. In J-P. Hautecoeur (Ed.), Ecological education in everyday life. ALPHA 2000 , Toronto, Buffalo \& London: University of Toronto Press.

English, L and Mayo, P (2012) Learning with Adults. A Critical Pedagogical Introduction, Rotterdam, Boston and Taipei: Sense.

Fletcher, C (2012). "Community-Based Participatory Research Relationships with Aboriginal Communities in Canada: An Overview of Context and Process."Pimatisiwin: A Journal of Aboriginal and Indigenous Community Health 1 (2003):27-62.Web.22Sept.20 <http://www.pimatisiwin.com/online/?page_id=116>.

Freire, P. (1970, 1993). Pedagogy of the Oppressed. New York and London: Continuum.

Freire, P. (1972). 'Education: Domestication or liberation ?' Prospects, 2, 173-181.

Freire, P. (1974). Authority versus authoritarianism (Audiotape, in series). Thinking with Paulo Freire. Sydney: Australian Council of Churches.

Freire, P. (1994). Pedagogy of hope. New York: Continuum.

Freire, P. (1998a). Pedagogy of freedom: Ethics, democracy and civic courage. Lanham, MD: Rowman \& Littlefield.

Freire, P. (1998b). Teachers as cultural workers: Letters to those who dare teach, Boulder, Co: Westview.

Gadotti, M., Freire, P. and Guimarães, S. (1995). Pedagogia: Dialogo e conflitto (B. Bellanova and F. Telleri, Eds.). Torino: Societa' Editrice Internazionale.

Galloway, G (2006), Fidel Castro Handbook, London: MQ Publications Ltd.

Ganz, M (2007) “Organizing for Democratic Renewal.” TPM Café, March 29.

Gargour, M (2007) La Terre Parle Arabe. The Land Speaks Arabic, Bad Movies and Rose Productions, film/documentary http://www.youtube.com/watch?v=nY3v-yht_6g

Gramsci, A. (1996), Lettere dal Carcere 1926 - 1937 (Letters from Prison 1926-1937), Santucci, A. (ed.), Palermo: Sellerio Editore.

Hammond, K ( 2012 ) 'Lifelong Learning in Palestine' in Holy Land Studies, Vol.11, No. 1, 79-85.

IME ( n.d )"How Many Palestinian Refugees Are There?" Http://imeu.net/news/article0038.shtml. New York: The Institute for Middle East Understanding, Web. 20 Sept. 2012.

Kane, L. (2001). Popular education and social change in Latin America. London: Latin American Bureau.

King, M. E (2007) A Quiet Revolution: The First Palestinian Intifada and Nonviolent Resistance, New York: Nation Books.

"Um Zohear,65,Palestinian Women, Learning Experience from Mother to Mother." Interview by Mohammad Shanti. AlQuds Newspaper [Jerusalem] 8 Nov. 2012: 35. Print

Lê Thánh Khôi. (2000). Il Mediterraneo e il dialogo fra le civilta.9The Mediteranean and the dialogue among civilisations) In G. Pampanini (Ed.), Un mare di opportunita'. Cultura e educazione nel Mediterraneo del lll Millenio (A sea of opportunities. Culture and education in the Mediterranean of the Third Millennium), Rome: Armando Editore.

Little, E (2012) "Towards an aesthetics of community based theatre. PART II: Avoiding the Missionary Position...' Communityengagedtheatre.ca, n.d. Web. 20 Nov.

Http://www.communityengagedtheatre.ca. 
Lockman, Z and Beinin, J (eds.) (1989) Intifada. The Palestinian uprising against the Israeli occupation, Cambridge MA: South end Press.

Masalha, N (2012), The Palestine Nakba: Decolonising History, Narrating the Subaltern, Reclaiming Memory, London and New York: Zed Books.

Mayo, P (2004; 2009) Liberating Praxis. Paulo Freire's Legacy for Radical Education and Politics, Westport, Connecticut: Praeger (2004 HB), Rotterdam, Boston and Taipei: Sense (pbk, 2009).

Mayo, P (2012), 'Critical pedagogy, Freirean and Other Approaches', Lifelong Learning in Palestine Project Meeting, University of Glasgow 21-25 August, video http://vimeo.com/67936029

Sacco, J (2002). Palestine, Seattle, Washington: Fantagraphics Books.

Said, E (1993) Culture and imperialism. London, Sydney, Melbourne, Auckland, Johannesburg: Vintage.

Shor, I (!980, 1987) . Critical Teaching and Everyday Life. Chicago and London: University of Chicago Press.

Shor, I., and Freire, P. (1987). Pedagogy for liberation .Dialogues on transforming education. Westport, CT: Bergin \& Garvey.

Taking Liberties Collective (1989), Learning the hard way - women's oppression in men's education, Macmillan, London.

Torres, C.A (2013) Political Sociology of Adult Education, Rotteram and Taipei: Sense.

Wallace-Murphy, T (2006), What Islam did for Us. Understanding Islam's Contribution to Western Civilization, London: Watkins Publishing

Waugh, C (2009), Plebs. The Lost Legacy of Independent Working Class Education. Occasional paper. Sheffield: Post 16 Educator. 